\title{
Rencana lansekap wisata berbasis aspek 4-A di kawasan pesisir Batu Bolong, Desa Canggu, Kabupaten Badung, Provinsi Bali
}

\author{
Ayu Ratih Widhi Astuti ${ }^{1}$, Gusti Alit Gunadi ${ }^{1}$, Ni Wayan Febriana Utami² \\ 1. Prodi Agroekoteknologi, Fakultas Pertanian, Universitas Udayana, Indonesia \\ 2. Prodi Arsitektur Pertamanan, Fakultas Pertanian, Universitas Udayana, Indonesia \\ *E-mail: gunadiya@gmail.com
}

\begin{abstract}
Landscape tourism plan based on aspect of 4-A at Batu Bolong coastal area, Canggu Village, Badung Regency, Bali Provice. Badung regency is a place that has spacious coastal landscape and much developed for tourist area. However, its potential needs to be optimized. One of attractive coastal area in Badung is Batu Bolong which is located in Canggu village, North Kuta district. Tourism is a commodity product which is created to respond to the society needs by considering four basic aspects that have to be met as a totality product. This research aims to explore both potencies and constraints within the Batu Bolong coastal area towards tourism development so it would be able to determine development planning concept based on aspect of 4-A (attractions, accessability, amenities, ancilliary) offering concept. The research method used consists of several stages i.e. inventory, analysis, synthesis and concept. The results show that based on the inventory and analysis of biophysical, socio-cultural and 4-A aspects of tourism offer on the landscape development were produce a spatial concept, concept circulation, greenery concept and finally resulted a block plan of 4-A aspectbased landscape management plan. This concept will be support the activities of the marine and religious tourism plan in Batu Bolong.
\end{abstract}

Keywords: Aspects 4 A of tourism offerings, coastal tourism Batu Bolong, landscape tourism plan.

\section{Pendahuluan}

Pengembangan wilayah pesisir di Indonesia salah satunya adalah melalui program-program pariwisata alam yang memanfaatkan potensi alam pesisir yang ada. Kegiatan pariwisata yang dikembangkan di wilayah pesisir sebagian besar kurang memperhatikan kualitas dari produk wisata alam pesisir tersebut. Menurut Medlik (1980) dalam Ardika (2003), pariwisata adalah suatu produk komoditas yang mana diciptakan untuk merespon kebutuhan masyarakat dengan memperhatikan empat (4) aspek dasar (4-A) yang harus dipenuhi oleh suatu produk-produk pariwisata sebagai sebuah totalitas produk, ada empat aspek (4A) yang harus diperhatikan dalam penawaran pariwisata, yaitu (1) Attractions (daya tarik); (2) Accessability (jaringan transportasilakses); (3) Amenities (fasilitas); dan (4) Ancilliary (kelembagaan).

Kabupaten Badung merupakan salah satu kabupaten yang memiliki wilayah pesisir yang cukup luas dan banyak dikembangkan untuk daerah wisata. Namun potensi pariwisata yang dimiliki masih perlu dioptimalkan. Salah satunya yaitu kawasan pesisir Batu Bolong yang terletak di desa Canggu kecamatan Kuta Utara. Kawasan Pesisir Batu Bolong perlu memperhatikan empat aspek dasar penawaran pariwisata dalam pengembangan lansekap wisata.

Rumusan masalah dari penelitian ini yaitu bagaimana menggali potensi dan kendala pada aspek biofisik, sosial budaya dan aspek 4-A penawaran pariwisata terhadap pengembangan lansekap wisata pesisir Batu Bolong sehingga dapat dirumuskan konsep rencana lansekap wisata berbasis aspek 4-A di kawasan pesisir Batu Bolong. Tujuan dari penelitian ini adalah untuk mengetahui potensi dan kendala pada aspek biofisik, sosial budaya dan aspek 4-A terhadap pengembangan lansekap wisata pesisir Batu Bolong dan dapat menentukan konsep dalam merencanakan lansekap wisata berbasis aspek 4-A di kawasan pesisir Batu Bolong.

\section{Metode}

\subsection{Tempat dan Waktu Penelitian}

Penelitian ini dilaksanakan di kawasan kompleks Pura Kahyangan Jagat Batu Bolong, Desa Canggu, Kecamatan Kuta Utara, Kabupaten Badung, Provinsi Bali (Gambar 1). Waktu Penelitian dilakukan mulai Maret 2016 sampai dengan Juli 2016. 


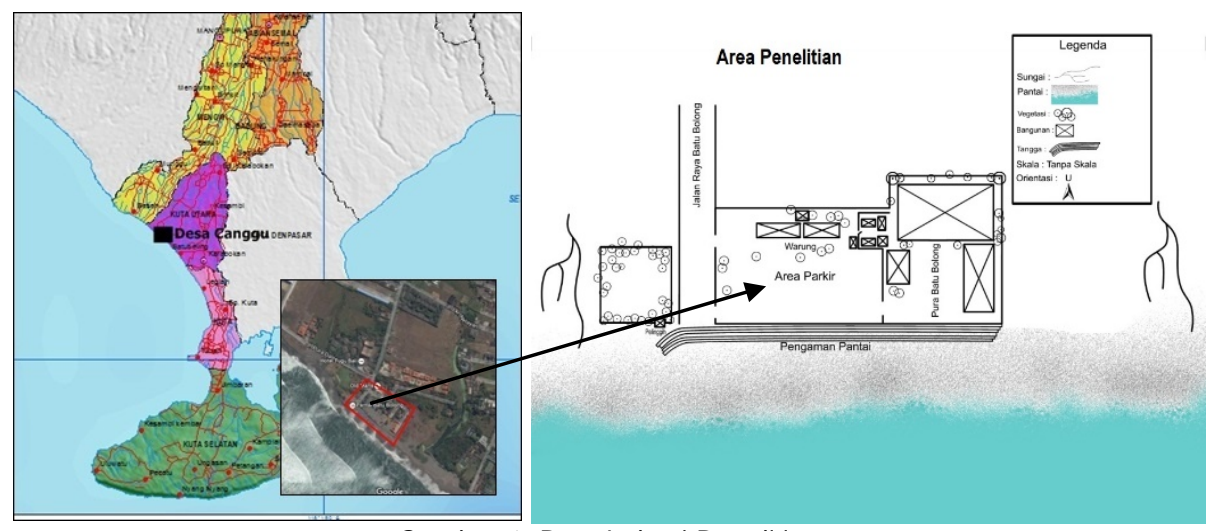

Gambar 1. Peta Lokasi Penelitian

(Sumber: BAPPEDA Kabupaten Badung dan Google Maps 2016)

\subsection{Bahan dan Alat Penelitian}

Penelitian ini memerlukan beberapa piranti lunak dan alat antara lain : perangkat komputer untuk mengolah data dan gambar dengan piranti lunak berupa Corel Draw X6 Graphic, Adobe Photoshop CS 6 dan Google Earth Pro, kamera digital untuk dokumentasi gambar/ foto di lapangan dan alat tulis untuk keperluan survey.

\subsection{Metode Penelitian}

Metode yang digunakan dalam penelitian ini adalah metode survey dengan teknik observasi, wawancara, dan studi pustaka. Tahap penelitian terdiri dari 4 tahap yang mengikuti metode Proses Berpikir Lengkap (Rachman, 1984) antara lain inventarisasi, analisis, sintesis dan konsep untuk merumuskan keterkaitan antar aspek yang dinilai berdasarkan data yang telah diperoleh. Pada tahap analisis, digunakan empat aspek penawaran pariwisata menurut Medlik (1980) dalam Ardika (2003), yaitu: attractions, accessibility, amenities, dan ancillary. Hasil akhir dari proses rencana ini yaitu berupa gambar blockplan yang merupakan hasil tumpang susun dari gambar tata ruang, tata sirkulasi, dan tata ruang hijau.

\section{Hasil dan Pembahasan}

\subsection{Inventarisasi Aspek Biofisik}

Kawasan pesisir Batu Bolong berlokasi di wilayah administrasi Desa Canggu, Kecamatan Kuta Utara,

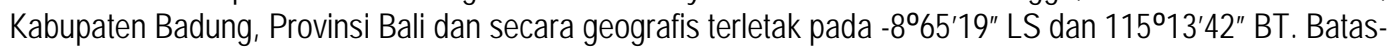
batas di sekeliling kawasan yaitu sebelah Utara dengan Desa Canggu, sebelah Barat dengan pantai Subak Catur, sebelah timur Pantai Nelayan dan sebelah Selatan dengan Samudra Hindia. Lokasi yang direncanakan untuk lansekap wisata berbasis aspek 4-A yaitu sebelah barat dari bangunan Pura Batu Bolong dan sebelah selatan Bangunan Pura yaitu pesisir pantai Batu Bolong. Akses menuju kawasan pesisir Batu Bolong sangat mudah dijangkau karena berada di jalan provinsi yang menghubungkan Denpasar-Tabanan melalui jalan Raya Tanah Lot jalan ini juga merupakan jalan menuju tempat wisata Tanah Lot. Batas rencana tapak yaitu area Pura Batu Bolong dengan luas lahan $\pm 1,1$ ha, sebelah barat dari bangunan Pura Batu Bolong dengan luas lahan \pm 20 are, pesisir pantai Batu Bolong dengan panjang pantai $\pm 2,5 \mathrm{~km}$, lebar dari bibir pantai $\pm 50 \mathrm{~m}$ dan dari bibir pantai menuju laut $\pm 100 \mathrm{~m}$.

Gambaran kondisi iklim kawasan pesisir Batu Bolong selama periode lima tahun (2011-2015) meliputi data curah hujan yang mencapai $1740 \mathrm{~mm}$ dengan rata-rata curah hujan bulanan tertinggi terjadi pada bulan Desember $297 \mathrm{~mm}$ dan terendah terjadi pada bulan September $6 \mathrm{~mm}$, suhu rata-rata bulanan berkisar $24^{\circ} \mathrm{C}$ $27,9^{\circ} \mathrm{C}$ dengan suhu rata-rata maksimum tertinggi terjadi pada bulan November sebesar $31,4^{\circ} \mathrm{C}$ dan suhu rata-rata minimum terendah terjadi pada bulan Juli dan September sebesar $23,7^{\circ} \mathrm{C}$. Rata-rata kelembaban udara bulanan cukup tinggi berkisar antara 77,6-81,6 \% dengan kelembaban tahunan 79\%, arah dan kecepatan angin di kawasan wisata pesisir Batu Bolong menunjukan pada musim penghujan (Oktober-April) dominan dari arah timur dan tenggara (BPS Kabupaten Badung, 2011-2015), sedangkan data pasang surut, arus dan gelombang tinggi merupakan data pengamatan tahun 2016 yaitu tipe pasang surut campuran dominan ganda adalah dalam satu hari terjadi dua kali pasang dan dua kali surut, sedangkan tinggi gelombang sekitar 2,5-3 meter dengan panjang gelombang mencapai 100-200 meter, periode 8,5 detik dan arah dominan dari tenggara ke barat laut (BMKG Wilayah III Denpasar, 2016).

Untuk karakter jenis tanah pada tapak adalah jenis tanah latosol, sedangkan pada area pantai Batu Bolong terdapat jenis pasir dengan warna dominan hitam yang berasal dari pengikisan bebatuan yang dibawa oleh aliran sungai. Kawasan pesisir Batu Bolong berada pada wilayah dataran rendah dengan ketinggian 
tempat 0-19 m dpl (Google Earth Pro, 2016). Tapak pesisir Batu Bolong memiliki topografi yang relatif datar dengan bentuk lahan yang biasa sampai bergelombang. Keadaan sebagian tapak kawasan pesisir Batu Bolong dari segi visual tidak memiliki kualitas visual yang mendukung (bad view) dikarenakan lansekap pada kawasan belum tertata secara maksimal. Namun, pada sebelah selatan area Pura terdapat pengaman pantai yang menjadi pembatas menuju area pantai ini memberikan kualitas visual yang mendukung bagi kawasan wisata karena berhadapan langsung dengan pemandangan pantai Batu Bolong.

Sedangkan keragaman tumbuhan dan hewan di wilayah perairan dapat ditemui saat kondisi air sedang surut, tumbuhan tersebut antara lain beberapa jenis rumput laut dan berbagai jenis moluska serta beberapa jenis ikan yang hidup pada celah-celah diantara bebatuan karang. Jenis vegetasi disekitar Pura Batu Bolong didominasi oleh tanaman pantai antara lain Waru Laut (Hibiscus tiliaceus), Pandan Pantai (Pandanus tectorius), Ketapang (Terminalia catappa), Tapak Kuda (Ipomea pes-caprae) dan Kelapa (Cocos nucifera), sedangkan vegetasi yang ada di area Pura merupakan vegetasi tambahan yang ditanam setelah pembangunan Pura Kahyangan Jagad Batu Bolong.

\subsection{Inventarisasi Aspek Sosial Budaya}

Kawasan wisata Pesisir Batu Bolong merupakan salah satu wisata pesisir yang terdapat di daerah kecamatan Kuta Utara. Nama dari wisata pesisir ini diambil dari nama sebuah Pura Kahyangan Jagad yang ada di kawasan pesisir tersebut yaitu Pura Batu Bolong. Wisatawan yang melakukan kunjungan ke kawasan ini didominasi oleh wisatawan dari Australia, Jepang dan Inggris. Menurut penjaga keamanan (Pecalang) pesisir Batu Bolong, rata-rata jumlah kunjungan di Wisata Pesisir Batu Bolong yang melakukan aktifitas wisata bahari mencapai 200 hingga 500 orang per hari yang didominasi oleh wisatawan dari Australia, Jepang dan Inggris. Peningkatan kunjungan terjadi pada saat liburan musim panas yaitu pada bulan Juli hingga bulan September yang mencapai jumlah kunjungan 800 hingga 1000 orang perhari.

Wisata Pesisir Batu Bolong dikelola oleh Pengempon Pura yang meliputi tiga banjar adat di Desa Canggu yaitu Banjar Pipitan, Banjar Kayu Tuung, dan Banjar Uma Buluh. Luas area Pura Kahyangan Jagat Batu Bolong sekitar $6000 \mathrm{~m}^{2}$ yang dibagi menjadi tiga bagian berdasarkan konsep Tri Mandala. Pura ini memiliki 10 unit bangunan suci dan sejumlah bangunan lainnya dengan langgam arsitektur tradisional Bali. Aktivitas religi yang rutin dilaksanakan setiap hari yaitu melakukan kegiatan persembahyangan dan yadnya (persembahan) oleh para pedagang maupun pengunjung wisata religi di Pura Batu Bolong. Piodalan Pura Kahyangan Jagat Batu Bolong dilaksanakan setiap enam bulan sekali tepatnya pada Buda Umanis Prangbakat dan melaksanakan Pujawali setiap hari Purnama, Tilem, Saraswati dan Melasti. Jumlah kunjungan yang melakukan aktivitas religi setiap hari Purnama dan Tilem mencapai 200 hingga 500 orang sedangkan pada saat hari Piodalan, Saraswati dan Melasti mencapai ribuan orang yang didominasi oleh penduduk lokal desa maupun luar desa.

\subsection{Inventarisasi Aspek 4-A Penawaran Pariwisata}

Aspek 4-A penawaran pariwisata yang terdapat pada kawasan pesisir Batu Bolong adalah pertama Attractions atau daya tarik. Kawasan Wisata Pesisir Batu Bolong memiliki dua daya tarik wisata yaitu daya tarik wisata bahari dan daya tarik wisata religi. Daya tarik wisata bahari meliputi kegiatan rekreasi di sekitar pantai seperti: berenang, berselancar, berjemur, berjalan - jalan atau berlari sepanjang pantai, dan berwisata kuliner sambil menikmati keindahan suasana pantai. Tingginya gelombang ombak yang dimiliki kawasan wisata ini menjadikan kawasan tersebut sebagai salah satu daya tarik wisata yang banyak dikunjungi oleh para peselancar lokal maupun mancanegara. Daya tarik wisata religi yang terdapat di Pesisir Batu Bolong adalah adanya bangunan suci berupa Pura yaitu Pura Kahyangan Jagat Batu Bolong yakni tempat persembahyangan bagi masyarakat umum. Selain melakukan kegiatan persembahyangan, wisatawan lokal maupun mancanegara datang hanya untuk melihat keunikan arsitektur bangunan Pura Kahyangan Jagat Batu Bolong.

Aksesibilitas menuju kawasan wisata pesisir Batu Bolong tergolong mudah untuk dijangkau dikarenakan kawasan tersebut dilintasi jalan provinsi Denpasar-Tabanan melalui jalan Raya Tanah Lot dengan kondisi jalan yang cukup baik untuk dilalui. Selain jalan utama yang berupa jalan provinsi, masing-masing desa yang ada di Kecamatan Kuta Utara termasuk desa Canggu juga sudah ada jalan penghubungnya dengan kondisi jalan yang cukup baik. Jarak kawasan dari pusat Kota Denpasar $\pm 8 \mathrm{~km}$ dan menuju ibukota kecamatan $\pm 2,5 \mathrm{~km}$, sedangkan jarak dari Bandara Ngurah Rai $\pm 12 \mathrm{~km}$. Akses untuk mencapai kawasan wisata pesisir Batu Bolong dapat dicapai dengan kendaraan pribadi roda dua maupun roda empat dan transportasi umum karena disana sudah terdapat area parkir yang cukup memadai.

Ketiga adalah Amenities atau fasilitas. Fasilitas yang terdapat di kawasan wisata pesisir Batu Bolong adalah fasilitas akomodasi dan usaha kuliner untuk menunjang kegiatan wisata religi dan wisata bahari di wisata pesisir Batu Bolong. Fasilitas yang ada yaitu meliputi fasilitas utama, fasilitas umum dan fasilitas penunjang. Fasilitas utama yaitu tersedianya dua organisasi selancar yang beroperasi menyediakan fasilitas penyewaan papan selancar dan pelatihan olahraga selancar. Fasilitas umum seperti area parkir, toilet, warung 
makanan dan minuman, tempat sampah, serta papan informasi masih dipandang kurang memadai dalam hal jumlah dan penataan tempat. Fasilitas penunjang lainnya yang berada di sekitar kawasan wisata yaitu terdapat hotel-hotel, penginapan, villa, home stay, restoran, bar and café, club, tempat layanan kesehatan seperti puskesmas dan praktek dokter umum, tempat ibadah serta fasilitas keamanan yang cukup baik dari Pecalang Desa Adat Canggu dan juga terdapat Polsek Kuta Utara yang berjaga 24 Jam di depan Kantor Desa Canggu.

Aspek terakhir adalah Ancilliary atau kelembagaan. Kawasan wisata pesisir Batu Bolong memiliki kelembagaan pemerintah yang terstruktur, koordinasi tugas, wewenang dan tanggung jawab antar sektor pemerintah pada tingkat tertentu di mulai dari tingkat desa, kecamatan, kebupaten, provinsi hingga tingkat pusat. Wisata pesisir Batu Bolong saat ini masih dikelola secara umum oleh Desa Adat Canggu dan khususnya dikelola oleh tiga Banjar Adat yaitu Banjar Pipitan, Banjar Kayutuung, dan Banjar Uma Buluh. Kawasan ini memiliki struktur pengelola yaitu penasehat, ketua, sekretaris, bendahara, dan penjaga/pecalang yang merupakan masyarakat dari pengempon pura, sedangkan untuk petugas kebersihan dikelola langsung dari DKP Kabupaten Badung.

\subsection{Analisis Sintesis}

Pada tahap analisis, data yang telah diperoleh dari berbagai aspek kemudian diolah sehingga diperoleh potensi dan kendala yang terdapat pada tapak. Tahap sintesis dikembangkan dengan membuat alternatif-alternatif rencana lansekap wisata berdasarkan aspek 4-A penawaran pariwisata dengan mengusahakan pemanfaatan optimal potensi dan pemecahan masalah yang timbul sehingga mendapatkan suatu konsep pembagian ruang yang tepat dan sesuai. Berbagai solusi dan pemecahan masalah pada tahap inventarisai dapat dilihat pada Tabel 1 analisis sintesis.

Tabel 1. Analisis dan Sintesis

\begin{tabular}{|c|c|c|c|c|}
\hline \multirow[b]{2}{*}{ Unsur Lansekap } & \multicolumn{3}{|c|}{ Analisis } & \multirow{2}{*}{$\begin{array}{l}\text { Sintesis } \\
\text { Alternatif tindakan }\end{array}$} \\
\hline & Potensi & Kendala & $\begin{array}{c}\text { Pemanfaatan potensi } \\
\text { dan pemecahan kendala }\end{array}$ & \\
\hline \multicolumn{5}{|l|}{ I. Aspek Biofisik } \\
\hline 1. Iklim & $\begin{array}{l}\text { - Keadaan iklim } \\
\text { relatif nyaman } \\
\text { untuk } \\
\text { beraktifitas. }\end{array}$ & $\begin{array}{l}\text { - Pada sebagian area } \\
\text { sedikit panas. }\end{array}$ & $\begin{array}{l}\text { - Tanaman untuk } \\
\text { meredam panas karena } \\
\text { tingginya intensitas } \\
\text { cahaya. }\end{array}$ & $\begin{array}{l}\text { - Penambahan } \\
\text { tanaman peneduh, } \\
\text { seperti pohon } \\
\text { ketapang (Teminalia } \\
\text { catappa) dan waru } \\
\text { laut (Hibiscus } \\
\text { tiliaceus). }\end{array}$ \\
\hline 2. Tanah & $\begin{array}{l}\text { - Tanah bersifat } \\
\text { subur. }\end{array}$ & $\begin{array}{l}\text { - Sebagian tanah tidak } \\
\text { kuat untuk fondasi } \\
\text { struktur bangunan. }\end{array}$ & $\begin{array}{l}\text { - Potensial untuk } \\
\text { penambahan vegetasi. } \\
\text { - Bahan untuk } \\
\text { memperkuat sifat tanah. }\end{array}$ & $\begin{array}{l}\text { - Penambahan } \\
\text { limpstone untuk } \\
\text { fondasi struktur tanah. }\end{array}$ \\
\hline 3. Topografi & $\begin{array}{l}\text { - Relatif datar } \\
\text { sehingga mudah } \\
\text { dimodifikasi. }\end{array}$ & $\begin{array}{l}\text { - Rawan terkena abrasi } \\
\text { pantai. }\end{array}$ & $\begin{array}{l}\text { - Topografi mendukung } \\
\text { rencana aktivitas. } \\
\text { - Tanaman pencegah } \\
\text { abrasi pantai. }\end{array}$ & $\begin{array}{l}\text { - Meminimalisir } \\
\text { terjadinya abrasi } \\
\text { pantai dengan } \\
\text { penambahan } \\
\text { tanaman pencegah } \\
\text { abrasi pantai, seperti } \\
\text { tanaman Tapak Kuda } \\
\text { (Ipomea pes-caprae), } \\
\text { Ketapang (Terminalia } \\
\text { catappa),Waru Laut } \\
\text { (Hibiscus tiliaceus), } \\
\text { dan Pandan Pantai } \\
\text { (Pandanus tectorius), }\end{array}$ \\
\hline 4. Visual & $\begin{array}{l}\text { Peman } \\
\text { dangan pantai } \\
\text { yang indah. }\end{array}$ & $\begin{array}{l}\text { - Beberapa fasilitas } \\
\text { kurang tertata. } \\
\text { - } \quad \text { Banyak sampah } \\
\text { berserakan. }\end{array}$ & $\begin{array}{l}\text { - Memanfaatkan visual } \\
\text { pantai dan bangunan } \\
\text { arsitektur pura sebagai } \\
\text { daya tarik wisata. }\end{array}$ & $\begin{array}{l}\text { - Penataan fasilitas, } \\
\text { meningkatkan } \\
\text { kebersihan dan }\end{array}$ \\
\hline
\end{tabular}




\begin{tabular}{|c|c|c|c|c|}
\hline \multirow[b]{2}{*}{ Unsur Lansekap } & \multicolumn{2}{|r|}{ Analisis } & \multicolumn{2}{|r|}{ Sintesis } \\
\hline & Potensi & Kendala & $\begin{array}{c}\text { Pemanfaatan potensi } \\
\text { dan pemecahan kendala }\end{array}$ & Alternatif tindakan \\
\hline & $\begin{array}{l}\text { - Keunikan } \\
\text { bangunan } \\
\text { arsitektur Pura } \\
\text { Batu Bolong. }\end{array}$ & & $\begin{array}{l}\text { • Meminimalisir visual } \\
\text { yang buruk (bad view) }\end{array}$ & $\begin{array}{l}\text { penambahan tempat } \\
\text { sampah. }\end{array}$ \\
\hline $\begin{array}{l}\text { 5. Vegetasi dan } \\
\text { satwa }\end{array}$ & $\begin{array}{l}\text { - Tanaman pantai } \\
\text { yang alami. }\end{array}$ & $\begin{array}{l}\text { - Variasi jenis tanaman } \\
\text { sedikit. Beberapa } \\
\text { penempatan vegetasi } \\
\text { tidak sesuai fungsi. }\end{array}$ & $\begin{array}{l}\text { - Memanfaatkan } \\
\text { vegetasi dan satwa } \\
\text { sebagai daya tarik } \\
\text { wisata. }\end{array}$ & $\begin{array}{l}\text { - Menambah variasi } \\
\text { jenis vegetasi dengan } \\
\text { menempatkan sesuai } \\
\text { fungsi vegetasi, yaitu } \\
\text { vegetasi dengan } \\
\text { fungsi penghalang, } \\
\text { pengarah, peneduh, } \\
\text { estetika dan } \\
\text { pencegah abrasi } \\
\text { pantai. }\end{array}$ \\
\hline $\begin{array}{l}\text { II. Aspek Sosial } \\
\text { Budaya }\end{array}$ & $\begin{array}{l}\text { - Kunjungan } \\
\text { wisatawan relatif } \\
\text { banyak. }\end{array}$ & $\begin{array}{l}\text { - Pada hari tertentu } \\
\text { jumlah pengunjung } \\
\text { wisata religi meningkat } \\
\text { pesat sehingga fasilitas } \\
\text { umum kurang } \\
\text { memadai. }\end{array}$ & $\begin{array}{l}\text { - Memanfaatkan } \\
\text { kedatangan pengunjung } \\
\text { untuk menambah } \\
\text { pemasukan masyarakat } \\
\text { desa. } \\
\text { - Menambah jumlah } \\
\text { fasilitas umum. }\end{array}$ & $\begin{array}{l}\text { - Memberi peluang } \\
\text { usaha untuk } \\
\text { masyarakat desa, } \\
\text { berupa usaha } \\
\text { dibidang makanan, } \\
\text { kerajianan maupun } \\
\text { penyedia transportasi } \\
\text { dan akomodasi } \\
\text { wisata. } \\
\text { - Menyediakan lebih } \\
\text { banyak fasilitas } \\
\text { umum, seperti toilet, } \\
\text { warung makanan dan } \\
\text { minuman, tempat } \\
\text { sampah, serta papan } \\
\text { informasi. }\end{array}$ \\
\hline \multicolumn{5}{|c|}{ III. Aspek 4A Penawaran Pariwisata } \\
\hline $\begin{array}{l}\text { 1. Attractions } \\
\text { (daya tarik) }\end{array}$ & $\begin{array}{l}\text { - Kegiatan utama } \\
\text { wisata bahari } \\
\text { yaitu kegiatan } \\
\text { selancar. } \\
\text { - Terdapat Pura } \\
\text { Kahyangan } \\
\text { Jagat Batu } \\
\text { Bolong }\end{array}$ & $\begin{array}{l}\text { - Pada saat tertentu } \\
\text { kekurangan penyediaan } \\
\text { papan selancar. } \\
\text { - Tidak ada papan } \\
\text { informasi mengenai } \\
\text { jadwal kegiatan } \\
\text { upacara keagamaan. }\end{array}$ & $\begin{array}{l}\text { - Memanfaatkan } \\
\text { kegiatan wisata bahari } \\
\text { dan kegiatan wisata } \\
\text { religi sebagai daya tarik } \\
\text { wisata. } \\
\text { - Menambah fasilitas } \\
\text { kegiatan selancar dan } \\
\text { memasang papan- } \\
\text { papan informasi. }\end{array}$ & $\begin{array}{l}\text { - Membentuk ruang } \\
\text { khusus dan mengajak } \\
\text { masyarakat desa } \\
\text { untuk meningkatkan } \\
\text { penyediaan fasilitas } \\
\text { kegiatan selancar. }\end{array}$ \\
\hline $\begin{array}{l}\text { 2. Accessability } \\
\text { (jaringan } \\
\text { transportasi/ } \\
\text { akses) }\end{array}$ & $\begin{array}{l}\text { - Mudah } \\
\text { dijangkau } \\
\text { karena berada } \\
\text { didekat jalan } \\
\text { provinsi } \\
\text { Denpasar- } \\
\text { Tabanan. } \\
\text { Kondisi jalan } \\
\text { baik. }\end{array}$ & $\begin{array}{l}\text { - Pada saat tertentu } \\
\text { kekurangan lahan parkir } \\
\text { dan memarkir } \\
\text { kendaraan dipinggir } \\
\text { jalan. }\end{array}$ & $\begin{array}{l}\text { - Dapat dijadikan salah } \\
\text { satu objek wisata yang } \\
\text { harus dikunjungi di } \\
\text { wilayah kuta utara. } \\
\text { Memperluas area parkir } \\
\text { pengunjung. }\end{array}$ & $\begin{array}{l}\text { - Memindahkan } \\
\text { bangunan warung dan } \\
\text { pedagang kaki lima ke } \\
\text { lahan kosong di } \\
\text { sebelah barat parkir. }\end{array}$ \\
\hline $\begin{array}{l}\text { 3. Amenities } \\
\text { (fasilitas) }\end{array}$ & $\begin{array}{l}\text { - Tersedia } \\
\text { fasilitas utama, } \\
\text { fasilitas umum }\end{array}$ & $\begin{array}{l}\text { - Fasilitas kurang } \\
\text { tertata. } \\
\text {. }\end{array}$ & $\begin{array}{l}\text { - Memberi kenyamanan } \\
\text { dan memenuhi } \\
\text { kebutuhan pengunjung }\end{array}$ & $\begin{array}{l}\text { - Menata penempatan } \\
\text { fasilitas wisata. }\end{array}$ \\
\hline
\end{tabular}


Lanjutan Tabel 1

\begin{tabular}{|c|c|c|c|c|}
\hline \multirow[b]{2}{*}{ Unsur Lansekap } & \multicolumn{2}{|r|}{ Analisis } & \multicolumn{2}{|r|}{ Sintesis } \\
\hline & Potensi & Kendala & $\begin{array}{c}\text { Pemanfaatan potensi } \\
\text { dan pemecahan kendala }\end{array}$ & Alternatif tindakan \\
\hline & $\begin{array}{l}\text { dan fasilitas } \\
\text { penunjang. }\end{array}$ & & $\begin{array}{l}\text { saat berwisata. } \\
\text { Meningkatkan kualitas } \\
\text { fasilitas wisata. }\end{array}$ & \\
\hline $\begin{array}{l}\text { 4. Ancilliary } \\
\text { (kelembagaa } \\
\text { n) }\end{array}$ & $\begin{array}{l}\text { - Memiliki } \\
\text { Pengelolaan } \\
\text { yang terstruktur. }\end{array}$ & $\begin{array}{l}\text { - Keterpaduan antar } \\
\text { sektoral belum terlihat, } \\
\text { pihak lembaga yang } \\
\text { mengelola masih } \\
\text { bergerak dengan cara } \\
\text { dan jalan mereka } \\
\text { masing-masing. }\end{array}$ & $\begin{array}{l}\text { - Memberikan } \\
\text { keamanan dan } \\
\text { kenyamanan bagi } \\
\text { pengunjung. }\end{array}$ & $\begin{array}{l}\text { - Pihak pengelola } \\
\text { bekerjasama dengan } \\
\text { intansi terkait untuk } \\
\text { menyediakan dan } \\
\text { membenahi fasilitas- } \\
\text { fasilitas pendukung } \\
\text { pada tapak. }\end{array}$ \\
\hline
\end{tabular}

\subsection{Konsep Dasar}

Konsep merupakan pengembangan dari potensi dan masalah yang telah dilakukan pada tahap sintesis. Konsep terdiri dari konsep dasar dan konsep pengembangan. Konsep dasar rencana lansekap wisata di kawasan pesisir Batu Bolong adalah merencanakan lansekap wisata pesisir yang memperhatikan aspek 4A yang merupakan dasar suatu daerah wisata sehingga wisata pesisir dapat memberikan kenyamanan dan memenuhi kebutuhan pariwisata masyarakat dengan baik, serta pembangunan wilayah pesisir dapat lebih berkelanjutan tanpa menimbulkan permasalahan-permasalahan baru. Konsep ini diambil berdasarkan pertimbangan lansekap wisata pesisir Batu Bolong yang berada di dalam kawasan pesisir serta mengoptimalkan lahan dikawasan ini yang belum difungsikan secara maksimal sebagai suatu kawasan wisata.

\subsection{Konsep Pengembangan}

Konsep pengembangan merupakan penjabaran dari konsep dasar yang dibagi menjadi beberapa konsep yaitu konsep ruang, konsep sirkulasi, konsep tata hijau dan blockplan rencana lansekap wisata berbasis aspek 4-A di kawasan pesisir Batu Bolong.

\subsubsection{Tata Ruang}

Konsep tata ruang bertujuan untuk menata dan mengalokasikan fungsi-fungsi yang akan dikembangkan dalam tapak. Terdapat dua ruang yang akan dibentuk yaitu area untuk penerimaan dan area aktivitas. Area penerimaan ini berfungsi sebagai pintu masuk utama untuk memasuki kawasan wisata pesisir Batu Bolong. Area penerimaan juga berfungsi menarik pengunjung agar tertarik mengunjungi kawasan wisata pesisir Batu Bolong. Pada area penerimaan dibuat karakter ruang yang bersifat astetik dan informatif mengenai kegiatan wisata di dalam kawasan tapak. Letak area penerimaan ini dibuat strategis yaitu di area masuk kawasan dekat dengan tempat parkir. Area aktivitas berfungsi sebagai pusat kegiatan wisata. Dalam area ini terdapat berbagai kegiatan wisata yang berhubungan dengan lingkungan tapak. Area aktivitas ini terdiri dari beberapa bagian yaitu area aktivitas religi di Pura Batu Bolong, area aktivitas berjemur, area aktivitas berenang, area aktivitas berjalan-jalan atau berlari, area aktivitas wisata kuliner dan area aktivitas selancar. Ruang-ruang dalam area aktivitas ini bersifat aktif dan berkaitan dengan aktivitas rekreasi wisata religi dan rekreasi wisata bahari.

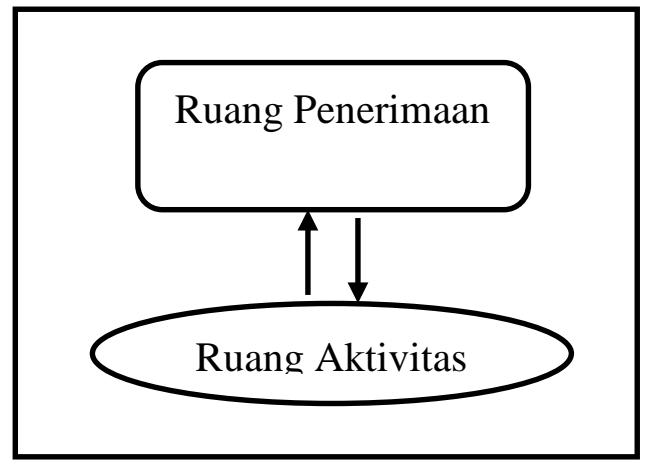

Gambar 2. Skema Ruang

Pada gambar 2 skema ruang menjelaskan bahwa keterkaitan antar ruang-ruang yang akan direncanakan. Area penerimaan berhubungan langsung dengan area aktivitas karena untuk mencapai ruang 
aktivitas harus terlebih dahulu melalui area penerimaan. Hubungan antar ruang akan dikembangkan dengan tujuan untuk mendukung kegiatan wisata yang akan direncanakan pada tapak. Objek/Atraksi, aktivitas dan fasilitas yang direncanakan disesuaikan dengan ruang dan aktivitas pengunjung. Tabel 2 menjelaskan hubungan antar ruang objek/atraksi, aktivitas dan fasilitas pada setiap rencana ruang.

Tabel 2. Hubungan Antar Ruang Objek/Atraksi, Aktifitas dan Fasilitas

\begin{tabular}{|c|c|c|c|c|c|c|}
\hline \multirow{2}{*}{\multicolumn{2}{|c|}{ Ruang }} & \multirow{2}{*}{\multicolumn{2}{|c|}{ Objek/Atraksi }} & \multirow{2}{*}{ Aktivitas } & \multicolumn{2}{|c|}{ Fasilitas } \\
\hline & & & & & Sarana & Prasarana \\
\hline \multicolumn{2}{|c|}{ 1.Area Penerimaan } & & & $\begin{array}{l}\text { a. Penerimaan } \\
\text { Pengunjung } \\
\text { b. Memarkir } \\
\text { Kendaraan }\end{array}$ & $\begin{array}{l}\text { - } \quad \text { Ruang } \\
\text { Penerimaan } \\
\text { - Areal Parkir }\end{array}$ & $\begin{array}{l}\text { - Papan Informasi } \\
\text { - Loket Parkir } \\
\text { - Papan Informasi } \\
\text { - Rambu-rambu } \\
\text { - Warung Makan } \\
\text { - Toilet }\end{array}$ \\
\hline \multirow{8}{*}{$\begin{array}{l}\text { 2.Area } \\
\text { Aktivita } \\
\mathrm{s}\end{array}$} & A. Area & 1. & Pura & c. Kegiatan & - Pura Kahyangan & - Papan Informasi \\
\hline & $\begin{array}{l}\text { Wisata } \\
\text { Religi }\end{array}$ & & $\begin{array}{l}\text { Kahyangan } \\
\text { Jagat Batu } \\
\text { Bolong }\end{array}$ & $\begin{array}{l}\text { Persembahyang } \\
\text { an di Pura Batu } \\
\text { Bolong }\end{array}$ & $\begin{array}{ll}\text { Jagat } & \text { Batu } \\
\text { Bolong } & \end{array}$ & $\begin{array}{l}\text { - Penyedia Alat dan } \\
\text { Bahan } \\
\text { Persembahyanga } \\
\text { n } \\
\text { - Tempat Sampah } \\
\text { - Warung Makan } \\
\text { - Toilet }\end{array}$ \\
\hline & $\begin{array}{l}\text { B. Area } \\
\text { Wisata } \\
\text { Bahari }\end{array}$ & 2. & Pantai & $\begin{array}{l}\text { d. Menikmati } \\
\text { Keindahan Alam } \\
\text { Pantai }\end{array}$ & - Tempat Duduk & $\begin{array}{l}\text { - Papan Informasi } \\
\text { - Tempat Sampah } \\
\text { - Warung Makan } \\
\text { - Toilet }\end{array}$ \\
\hline & & & $\begin{array}{l}\text { Sinar Matahari } \\
\text { Terik dan Pasir } \\
\text { Pantai }\end{array}$ & e. Berjemur & $\begin{array}{l}\text { - Hamparan } \\
\text { Pasir Pantai }\end{array}$ & $\begin{array}{l}\text { - Papan Informasi } \\
\text { - Kursi dan Payung } \\
\text { Berjemur }\end{array}$ \\
\hline & & & $\begin{array}{l}\text { Kejernihan Air } \\
\text { Pantai }\end{array}$ & f. Berenang & $\begin{array}{l}\text { - Area } \quad \text { Bibir } \\
\text { Pantai }\end{array}$ & $\begin{array}{l}\text { - Papan Informasi } \\
\text { - Rambu-rambu } \\
\text { - Pelampung }\end{array}$ \\
\hline & & & Pantai Berpasir & $\begin{array}{l}\text { g. Berjalan-jalan } \\
\text { atau berlari }\end{array}$ & $\begin{array}{l}\text { - Hamparan Pasir } \\
\text { Dekat Bibir } \\
\text { Pantai }\end{array}$ & - Papan Informasi \\
\hline & & & Kuliner & $\begin{array}{l}\text { h. Makan dan } \\
\text { Minum }\end{array}$ & $\begin{array}{l}\text { Bangunan } \\
\text { Warung Makan, } \\
\text { Restoran, cafe }\end{array}$ & $\begin{array}{l}\text { - Papan Informasi } \\
\text { - Tempat Sampah } \\
\text { - Toilet }\end{array}$ \\
\hline & & & $\begin{array}{l}\text { Gelombang } \\
\text { Tinggi }\end{array}$ & $\begin{array}{l}\text { i. Berselancar } \\
\text { (surfing) }\end{array}$ & $\begin{array}{l}\text { - Area Selancar } \\
\text { (surfing) }\end{array}$ & $\begin{array}{l}\text { - Papan Informasi } \\
\text { - Penyewaan } \\
\text { Papan Selancar } \\
\text { - Pelatih Selancar }\end{array}$ \\
\hline
\end{tabular}

\subsubsection{Tata Sirkulasi}

Konsep sirkulasi yang akan direncanakan merupakan jalur-jalur yang menghubungkan antar satu ruang ke ruang lainnya serta menghubungkan antara satu objek ke objek lainnya yang terdapat pada tapak. Pengembangan sirkulasi ini dilakukan berdasarkan kondisi kebutuhan tapak dan ruang-ruang yang ada, sehingga konsep sirkulasi adalah membagi jalur sirkulasi berdasarkan kegunaannya (Simond, 2006). Konsep sirkulasi dibuat rotasi, sehingga semua objek pada tapak akan dapat dilalui. Sirkulasi yang direncanakan berupa sirkulasi bagian luar dan sirkulasi bagian dalam. Sirkulasi bagian luar yang dimaksud yaitu sirkulasi utama yang menghubungkan area penerimaan dengan area aktivitas wisata. Sirkulasi bagian dalam merupakan sirkulasi yang menghubungkan satu objek ke objek lainya dalam area aktivitas wisata. Gambar 3 menjelaskan skema sirkulasi antar ruang. 


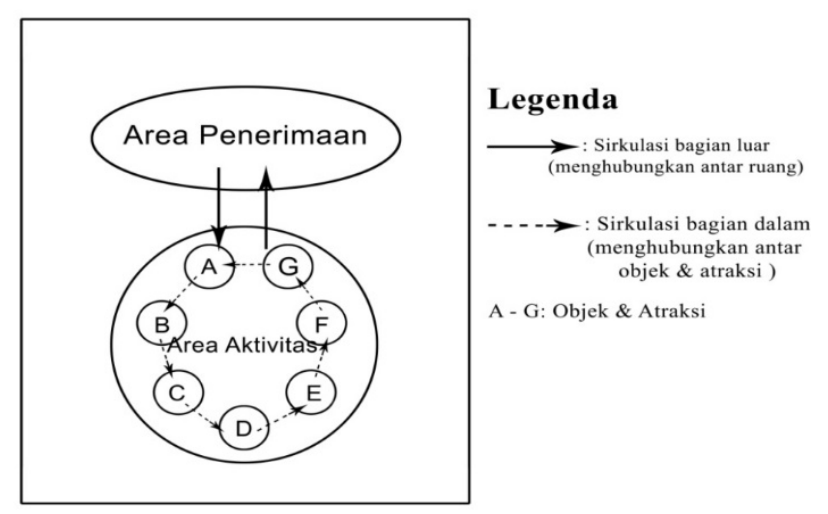

Gambar 3. Skema Sirkulasi Antar Ruang

Pada konsep sirkulasi menjelaskan area penerimaan menjadi akses utama untuk menuju area aktivitas, sedangkan area aktivitas dibuat sirkulasi memutar untuk melalui objek-objek wisata yang ada. Konsep sirkulasi dibuat memutar dan satu arah untuk menghindari terjadinya penumpukan pengunjung di satu ruang.

\subsubsection{Tata Hijau}

Konsep tata hijau dalam rencana lansekap wisata di kawasan pesisir Batu Bolong dengan menentukan vegetasi yang akan digunakan yaitu vegetasi dengan fungsi penghalang, pengarah, peneduh, estetika dan pencegah abrasi pantai. Vegetasi dengan fungsi penghalang digunakan sebagai penghalang pandangan dari dalam kearah luar tapak, dikarenakan kondisi visual di sekitar tapak kurang mendukung (bad view). Vegetasi fungsi pengarah digunakan untuk membuat kesan pengarah. Vegetasi fungsi peneduh digunakan untuk memberikan keteduhan terutama di ruang-ruang yang akan digunakan sebagai tempat berkumpul. Vegetasi fungsi estetika digunakan sebagai vegetasi yang menjadi pembeda (kontras) baik dari segi bentuk, bunga dan warna. Vegetasi fungsi pencegah abrasi pantai digunakan dengan memanfaat akar tanaman sehingga mampu menghambat terjadinya pengikisan pantai.

Pemilihan vegetasi dengan fungsi-fungsi tersebut ditentukan untuk mendukung ruang-ruang maupun aktivitas yang akan dibentuk pada tapak seperti pada vegetasi di ruang penerimaan digunakan vegetasi dengan fungsi estetika sedangkan pada ruang aktivitas terdapat vegetasi dengan fungsi pengarah, peneduh, penghalang, estetika dan vegetasi fungsi mencegah abrasi pantai ini disesuaikan dengan maksud dan tujuan dari pembentukan ruang-ruang tersebut.

\subsubsection{Blockplan}

Pembagian ruang berfungsi untuk mengatur fungsi ruang serta memberikan alur bagi pengunjung dalam berwisata di pesisir Batu Bolong. Ruang penerimaan berfungsi sebagai pintu masuk utama untuk memasuki kawasan wisata pesisir Batu Bolong. Ruang penerimaan diperuntukan sebagai ruang pusat informasi wisata. Rencana fasilitas yang terdapat di ruang penerimaan antara lain: loket karcis masuk wisata dan toilet. Terdapat dua pintu masuk yang akan direncanakan sebagai jalur akses sirkulasi pengunjung. Pintu masuk pertama akan menghubungkan areal parkir kendaraan dan pintu masuk kedua dibuat sebagai akses untuk menuju ruang aktivitas pantai.

Ruang aktivitas wisata merupakan ruang wisata utama yang terdapat di kawasan ini. Ruang aktivitas ini memiliki tujuh sub ruang yang dibuat menjadi objek dan atraksi wisata. Objek dan atraksi wisata yang akan direncanakan antara lain: a) area wisata religi Pura Kahyangan Jagat Batu Bolong, b) area menikmati keindahan pantai, c) area berjemur, d) area aktivitas berjalan-jalan, e) area berenang, f) area berselancar (surfing), dan g) area kuliner. Objek dan atraksi wisata tersebut dibuat dan disesuaikan dengan kondisi lahan yang terdapat pada tapak. Gambar 3 menjelaskan blockplan rencana lansekap wisata berbasis aspek 4-A di kawasan pesisir Batu Bolong. 


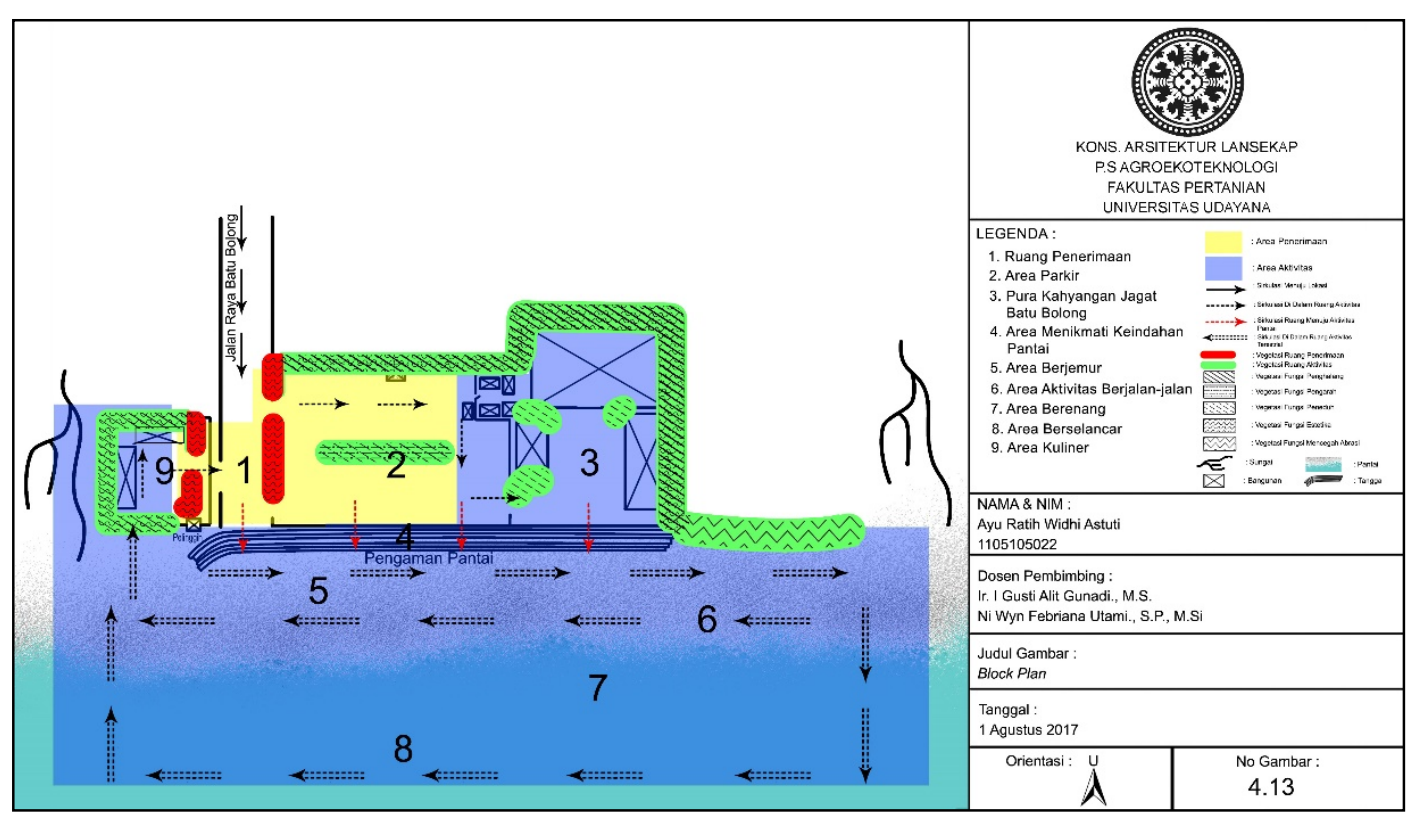

Gambar 3. Blockplan Rencana Lansekap Wisata Berbasis Aspek 4-A di Kawasan Pesisir Batu Bolong

\section{Simpulan dan Saran}

\subsection{Simpulan}

Berdasarkan hasil penelitian rencana lansekap wisata berbasis aspek 4-A di kawasan pesisir Batu Bolong Desa Canggu, dapat disimpulkan bahwa potensi-potensi wisata di kawasan pesisir Batu Bolong berdasarkan aspek penawaran pariwisata 4-A yaitu : Daya Tarik (Attractions): potensi utama yang menjadi daya tarik wisata pesisir Batu Bolong untuk dikunjungi yang dibagi menjadi 2 yaitu daya tarik wisata bahari dan daya tarik wisata religi, Aksesibilitas (Accessability) menuju kawasan wisata pesisir Batu Bolong sudah menunjang kegiatan wisata pesisir Batu Bolong, Fasilitas (Amenities) yang terdapat di wisata pesisir Batu Bolong yaitu fasilitas utama, fasilitas umum dan fasilitas penunjang yang nyaman untuk menunjang kegiatan wisata di kawasan pesisir Batu Bolong dan Kelembagaan (Ancillary) wisata pesisir Batu Bolong saat ini masih dikelola secara umum oleh Desa Adat Canggu dan khususnya dikelola oleh 3 Banjar Adat yaitu Banjar Pipitan, Banjar Kayutuung, dan Banjar Uma Buluh yang memiliki kelembagaan yang terstruktur dengan pengempon Pura Kahyangan Jagat Batu Bolong.

Hasil tumpang susun pada konsep tata ruang, tata sirkulasi dan tata hijau menghasilkan gambar blockplan kawasan. Pendekatan tersebut dibangun berbasis pada pengembangan aspek 4-A penawaran pariwisata yang terdapat di kawasan pesisir Batu Bolong.

\subsection{Saran}

Hasil penelitian rencana lansekap wisata berbasis aspek 4-A di kawasan pesisir Batu Bolong dapat dijadikan masukan dan pertimbangan bagi pihak pengelola agar dapat menyediakan dan membenahi fasilitasfasilitas pendukung yang dapat memberikan kenyamanan pada wisatawan, serta penelitian ini dapat dilanjutkan pada tahap perencanaan yang lebih detail pada objek-objek wisata yang telah direncanakan.

\section{Daftar Pustaka}

Ardika, 2003. Pariwisata Budaya Berkelanjutan: Refleksi dan Harapan di Tengah Perkembangan Global. Denpasar. Program studi Magister (S2) Kajian Pariwisata, Program Pascasarjana Universitas Udayana..

Bappeda Kabupaten Badung, 2013. Perda Kabupaten Badung Nomor 26 tahun 2013 tentang Rencana Tata Ruang Wilayah Kabupaten Badung tahun 2013-2033. Badung.

BMKG Wilayah III Denpasar, 2016. Informasi Maritim Kecamatan Kuta Utara Kabupaten Badung.Denpasar. BPS (Badan Pusat Statistik), 2011-2015. Badung Dalam Angka 2011-2015. Badan Pusat Statistik Badung.

Rachman, Z. 1984. Proses Berpikir Lengkap Merencana dan Melaksana dalam Arsitektur Lansekap. Makalah Diskusi pada Festival Tanaman VI Himagron (Tidak Dipublikasikan). Bogor.

Simond, J.O. 2006. Landscape Architecture. McGraw-Hill Book Co, Newyork. 